\title{
EKSISTENSI MADRASAH DALAM PENDIDIKAN INDONESIA
}

\section{Samsul Susilowati}

\author{
Dosen pada program studi PIPS dan PGMI UIN Malang
}

\begin{abstract}
The existence of madrasah in developing an education at Indonesia is very important, despite of many people consider that madrasah is a second institution in Indonesia of other education institution. However Madrasah be able to survive to develop an education in Indonesia, even Madrasah contribute to release the excellent graduations, and whose is able to glorify the Indonesia, especially in education aspect.
\end{abstract}

Keywords: Madrasah and Education

\section{A. Pendahuluan}

Keberadaan madrasah sangat diperlukan keberadaannya sebagai tempat murid-murid menerima ilmu pengetahuan agama secara teratur dan sistematis. Tetapi sebelum abad keempat Hijriyah atau sepuluh Miladiyah, madrasah tersebut belum tumbuh, dan baru mulai didirikan pertama kalinya sebuah mandrasah di kota Naisabur yaitu madrasah alBaehaqiyyah,(Ali;1994:30). Sebab-sebab madrasah ini didirikan, adalah karena masjid-masjid telah dipenuhi dengan halakah-halakah (pengajian) dari para guru dan murid-murid semakin berdesakan, sehingga mengganggu orang yang bersembahyang dari satu segi, dan segi lainnya ialah karena pesatnya perkembangan ilmu pengetahuan setelah makin berkembangnya kegiatan penerjemahan buku-buku berbahasa asing (non Arab) ke dalam bahasa Arab.

Adapun yang menjadikan madrasah ini paling penting fungsi dan peranannya ialah kelengkapan ruangan untuk belajar yang dikenal dengan ruangan muhadharanya (untuk berdiskusi) beserta bangunan-bangunan yang berkaitan dengannya, pengamanan bagi murid-murid dan gurugurunya. Dengan demekian, terlihatlah keberadaan eksistensi madrasah dalam membangun sumber daya manusia pada zaman itu.

Dalam konteks Indonesia, madrasah merupakan lembaga pendidikan Islam yang telah ada pada saat Indonesia memproklamasikan kemerdekaannya (M.Yunus; 1982;20). Yang merupakan sebagai lembaga pendidikan Islam yang didirikan atau swadaya masyarakat, madrasah sangat bervariasi, bergantung pada pemilik dan pendirinya. Karenanya, kualitas pendidikan di madrasah pun sangat bervariatif. Maka dengan demikian eksistensi madrasah dalam dunia pendidikan Indonesia sangat 
menentukan dalam perkembangan pendidikan yang ada di Indonesia, utamanya pendidikan yang notabene pendidikan agama Islam.

Untuk itu, madrasah dalam konteks pengembangan pendidikan Indonesia sangat menentukan. Sehingga tidak heran, ketika KH. Imam Zarkasyi dan A. Malik Fadjar memperjuangkan mati-matian untuk tidak mengatukan pendidikan agama Islam yang berada di bawah naungan Departemen Agama (Depag RI) dengan pendidikan Nasional yang di bawah naungan Departemen Pendidikan Nasional (Diknas). Karena pendidikan agama Islam mempunyai peran tersendiri, sehingga sangat tidak bisa untuk disatukan. Makanya madrasah dalam ini mempunyai andil perkembangan pendidikan ke depan, baik dalam konteks pendidikan agama maupun pendidikan umum.

\section{B. Makna dan Pergolakan Madrasah}

Makna madrasah dalam hal ini dikatakan bahwa kata "madrasah" adalah isim makan dari kata: darasa-yaduru wa durusan wa dirasatun, yang berarti: terhapus, hilang bekasnya, menghapus, mejadikan usang, melatih, mempelajari (Muhaimin; 2005:183). Dilihat dari pengertian ini, maka madrasah berarti merupakan tempat untuk mencerdaskan para peserta didik, menghilangkan ketidaktahuan atau memberantas kebodohan mereka, serta melatih keterampilan mereka sesuai dengan bakat, minat dan kemampuannya. Pengetahuan dan keterampilan seseorang akan cepat usang selaras dengan percepatan kemajuan ipteks dan perkembangan zaman, sehingga madrasah pada dasarnya sebagai wahana untuk mengembangkan kepekaan intelektual dan informasi, serta memperbarui pengetahuan, sikap dan keterampilan secara berkelanjutan, agar tetap up to date dan tidak cepat usang.

Senada juga dengan apa yang diungkapkan oleh A. Malik Fadjar bahwa madrasah berasal dari bahasa Arab. Secara harfiah, kata ini berarti atau setara maknanya dengan kata Indonesia "sekolah," yang notabene juga bukan kata asli dari bahasa kita. "sekolah," dialihkan dari bahasa asing, misalnya school ataupun scola. (Malik Fajar; 1998:111).

Madrasah mengandung arti tempat atau wahana anak menyenyam proses pembelajaran. Maksudnya, di madrasah itulah anak menjalani proses belajar secarah terarah, terpimpin, dan terkendali. Dengan demikian, secara teknis madrasah menggambarkan proses pembelajaran secara formal yang tidak berbeda dengan sekolah. Hanya dalam lingkup kultural, madrasah memiliki konotasi spesifik. Di lembaga ini anak memperoleh pembelajaran hal ihwal atau seluk-beluk agama dan keagamaan. Sehingga dalam pemakaiannya, kata madrasah lebih dikenal sebagai sekolah agama.

Kata madrasah, yang secara harfiah identik dengan sekolah agama, setelah mengarungi perjalanan peradaban bangsa diakui telah mengalami 
perubahan-perubahan walaupun tidak melepaskan diri dari makna asal; sesuai dengan ikatan budayanya, yakni budaya Islam.

Kehadiran madrasah dilatarbelakangi oleh keinginan untuk memberlaku- kan secara berimbang antara ilmu agama dengan ilmu pengetahuan umum dalam kegiatan pendidikan di kalangan umat Islam (Hasbullah;1996:66). Atau dengan kata lain madrasah merupakan perpaduan sistem pendidikan pesantren dengan sistem pendidikan kolonial.

Memang pada waktu itu terdapat dua sistem pendidikan yang sangat berbeda antara yang satu dengan yang lainnya. Di satu pihak umat Islam memiliki pesantren yang berorientasi agama, sementara pemerintah kolonial Belanda memperkenalkan sekolah-sekolah modern yang menganut sistem persekolahan dan mengembangkan pengetahuan umum seperti yang berkembang di dunia Barat. Hai ini sedikit banyak mempengaruhi sistem pendidikan pesantren yang telah berkembang di Indonesia.

Adanya perbedaan yang sangat kontradiktif antara kedua sistem pendidikan tersebut rupanya menggugah sebagian penduduk pribumi. Mereka menyadari akan pentingnya pendidikan umum, namun mengenyampingkan atau meninggalkan pola pendidikan pesantren adalah sesuatu yang amat berbahaya. Maka di sinilah kemudian lahir upaya untuk memadukannya, dengan mengembangkan sistem madrasah.

Bagaimanapun kesadaran seperti itu sangat diperlukan oleh umat Islam, sebab dari pengalaman historis, selama ratusan tahun dijajah Belanda, umat Islam selalu menjadi korbannya yang paling empuk. Hal ini disebabkan umat Islam pada waktu itu, boleh dikatakan bodoh dalam beberapa hal, terutama bidang keduniawian yang sesungguhnya juga menjadi sasaran risalah Islam. Belanda di samping sengaja membodohkan pribumi (umat Islam), umat Islam juga telah dibelokkan jalan hidupnya oleh para pendahulunya, supaya semata-mata melihat Islam sebagai tata cara ritual keagamaan belaka, dan sebaliknya agar membenci dunia dengan memandangnya sebagai sumber fitnah belaka.

Dengan demikian, setidak-tidaknya kehadiran madrasah sebagai lembaga pendidikan Islam mempunyai beberapa latarbelakang yaitu; 1) sebagai manifestasi dan realisasi pembaharuan sistem pendidikan Islam. 2) usaha penyempurnaan terhadap sistem pendidikan yang lebih memungkinkan lulusannya untuk memperoleh kesempatan yang sama dengan sekolah umum. 3) adanya sikap mental pada sementara golongan umat Islam, khususnya santri yang terpukau pada Barat sebagai sistem pendidikan mereka. 4) sebagai upaya untuk menjembatani antara sistem pendidikan tradisional yang dilaksanakan oleh pesantren dan sistem pendidikan modern dan hasil akulturasi. (Hasbullah;1996:98) 
Madrasah pertama yang didirikan di Indonesia adalah Madrasah Adabiyah di Padang Sumatera Barat, yang didirikan oleh Syekh Abdullah Ahmad pada tahun 1909. Pada mulanya Madrasah Adabiyah ini bercorak agama semata-mata, baru kemudian pada tahun 1915 berubah menjadi HIS (Holand Inland School) Adabiyah (Maksum;1999:99). HIS Adabiyah merupakan sekolah pertama yang memasukkan pelajaran umum ke dalamnya.

Sampai sekarang ini, dalam pergulatannya dengan dinamika internal umat Islam sendiri, madrasah yang tersebar di Nusantara ini mengambil beberapa pola/variasi, antara lain: 1) madrasah sebagai lembaga pendidikan dengan pola layaknya sekolah modern namun tetap berciri Islam, 2) madrasah sebagai lembaga pendidikan dengan pola terpadu; di mana pelajaran agama dan pelajaran umum diintegrasikan secara berimbang dalam kurikulum, 3) madrasah yang sepenuhnya bersifat keagamaan (diniyah); di mana mata pelajaran umum hanya menjadi suplemen (pelengkap) saja.

Pada awal perjalanannya, madrasah memang menghadapi beberapa rintangan, selain menyangkut pengintegrasian pelajaran agama vis a vis pelajaran umum, juga menyangkut persoalan kelembagaan dan peningkatan kualitas. Menyadari hal ini, sebagai institusi pemerintah yang otoritatif, Departemen Agama (Depag) membuat terobosan-terobosan baru. Pada tahun 1973 Depag mengambil kebijakan-kebijakan penting, di antaranya membenahi kurikulum dan struktur kelembagaan madrasah. Signifikansi kebijakan ini adalah (1) madrasah memiliki standar pendidikan berjenjang yang berlaku di setiap madrasah; (2) madrasah memiliki acuan yang detail soal mata pelajaran yang menjadi pedoman dalam proses pembelajaran di madrasah; (3) mata pelajaran umum dan kejuruan di madrasah mendapat landasan formal.

Kemudian, dengan lahirnya UU No. 2/1989 tentang Sistem Pendidikan Nasional (UUSPN), pemerintah Indonesia mengintegrasikan madrasah ke dalam Sistem Pendidikan Nasional. Konsekuensi ketentuan UUSPN 1989 ini adalah, madrasah dituntut mengadopsi dan menerapkan kurikulum pendidikan umum yang dikeluarkan Departemen Pendidikan dan Kebudayaan (Depdikbud) - sekarang menjadi Departemen Pendidikan Nasional (Depdiknas). Konsekuensi berikutnya adalah madrasah pada ketiga jenjangnya, mulai Ibtidaiyah hingga Aliyah, secara substansial berubah wajah yaitu menjadi sekolah umum berciri khas Islam. Bahkan pada tingkat Aliyah, madrasah ini tidak hanya membuka jurusan agama tetapi juga jurusan umum. Madrasah secara perlahan dituntut mengadopsi sebagian ciri kurikulum dan mata pelajaran modern, seperti matematika, sejarah, ilmu pengetahuan alam, dan geografi.

Tentu saja, dengan serangkaian kebijakan itu, tidak dimaksudkan untuk mengerdilkan misi madrasah, tetapi justru sebaliknya. Madrasah 
semakin diperkokoh secara institusional, operasional, dan sistem pembelajarannya. Dan sesuai dengan ketentuan UUSPN, yang memungkinkan madrasah membuka jurusan khusus ilmu agama, pada tingkat Madrasah Aliyah dikembangkan pula model Madrasah Aliyah Program Khusus (MAPK) (UU No 20. Th2003 Tentang Sisdiknas:15). Model ini bahkan telah dirintis sebelum UUSPN 1989 lahir, yaitu melalui Keputusan Menteri Agama No. 73 Tahun 1987, yang merupakan "penyempurnaan" dari SKB Tiga Menteri 1975. Dalam SK Menteri Agama itu disebutkan, pendirian MAPK dimaksudkan untuk mempersiapkan siswa agar memiliki kemampuan dasar di bidang ilmu agama Islam dan bahasa Arab, yang diperlukan untuk melanjutkan ke jenjang pendidikan yang lebih tinggi. Kurikulum MAPK bermuatan $70 \%$ pengetahuan agama dan 30\%, yaitu kebalikan dari muatan kurikulum Madrasah Aliyah pada umumnya. Setiap MAPK dilengkapi laboratorium, perpustakaan, mushalla, dan asrama. Pada perkembangan selanjutnya, MAPK berganti nama menjadi MAK (Madrasah Aliyah Keagamaan).

\section{Sekilas Pendidikan Indonesia}

Pada akhir-akhir ini realitas pendidikan di Indonesia membuahkan kepengapan, bahkan menyesakkan. Baris demi baris, alinea demi alinea, dan kolom demi kolom dalam media tulis hampir seluruhnya membahasakan kekecewaan, umpatan, hardikan, dan bahkan penafian terhadap seluruh kerja bangsa yang bernama "pendidikan." Pendidikan yang sejatinya meninggikan martabat manusia dan bangsa dinyatakan mempurukkannya. Pendidikan yang semestinya mencerdaskan manusia dan bangsa justru mewujudkan sesuatu yang berkebalikan. Pendidikan telah dinyatakan sebagai pembodohan. Pendidikan yang seharusnya memperkuat moralitas, kenyataannya justru melahirkan immoralitas. Apalagi dalam forum-forum lisan dan tatap muka, kekecewaan, umpatan, hardikan, dan penafian akan makna kerja pendidikan terasa terampil lebih telanjang sebab gurat-gurat luapan emosi lebih jelas terlihat.

Pendidikan memang hanyalah salah satu dari sekian banyak wilayah kehidupan (peradaban) manusia. Berbagai institusi atau pranata kehidupan lainnya mengalami nasib hampir serupa dengan pendidikan. Perubahan-perubahan dahsyat yang melanda semua wilayah kehidupan (peradaban) manusia diakui telah memunculkan persoalan-persoalan besar. Sekurang-kurangnya munculnya bentuk kesenjangan dimensi normatif dan ekspektasi dengan realitas yang begitu lebar. Sekurangkurangnya munculnya bentuk kesenjangan dimensi normatif dan ekspektasi dengan realitas yang begitu lebar. Kenyataan ini, sebagai contoh, terjadi pada bagian kehidupan yang tergolong esensial bagi manusia, yakni realitas agama. Secara normatif, ekspektasi kita terhadap agama kian kritis. Pranata agama dipersepsikan dan dinyatakan tidak 
mampu menghadirkan ketentraman dan kedamaian, bahkan ada yang berani mengungkapkan bahwa agama adalah sumber bencana.

Dalam sebuah keraguan, bahkan mungkin ketidakpercayaan, terhadap institusi pendidikan dapat dipahami dari beberapa segi. Pertama, fenomena pendidikan selalu memperlihatkan watak normatif dan imperatif. Tatkala perubahan sosial-struktural mendera dunia pendidikan, bisa dipastikan misi normatif dan imperatif pendidikan ikut berubah. Hal ini tidak berlangsung secara mudah. Ketegangan-ketegangan pasti terjadi. Bahkan, harapan-harapan kita akan realisasi fungsi (normatif-imperatif) pendidikan tidak segera terpenuhi.

Kedua, ketika pendidikan ditanggapi secara mikro, maka akan segera telihat kompleksitas permasalahannya. Pemahaman terhadap berbagai masalah dan usaha pemecahan memerlukan konsultasi ke berbagai disiplin keilmuan yang lain, seperti filsafat, sejarah, bahasa, antropologi, sosiologi, ekonomi, politik, biologi, informatika, manajemen, dan agama. Di samping itu, keahlian dan keterampilan mengintegrasikan informasi keilmuan yang berwatak lintas disiplin adalah niscaya. Sementara faktor kesabaran sering menggoda kita untuk berjalan pintas (instan) dan melakukan pemecahan-pemecahan seperti itu tentu sulit untuk memenuhi harapan masyarakat luas.

Ketiga, dari sudut kebijakan untuk semua, pendidikan di negara kita berhadapan dengan kenyataan kependudukan dan letak geografis yang menuntut kesiapan sumber daya dan sumber dana yang tidak kecil, dan terlebih sangat penting menuntut rasa keadilan. Kebijakan program yang skalanya kecil, ternyata mengimplikasikan kesulitan-kesulitan fisikmaterial, sosial, dan etik. Berdampingan dengan kenyataan ini, bisa disaksikan tumbuhnya ketidakpuasan terhadap pendidikan, bahkan hilangnya sebuah kepercayaan.

Keempat, bukan dimaksudkan sebagai "phobia" akan kenyataan globalisasi, tapi bahwa globalisasi telah menjadi sesuatu yang fenomenal. Tiba-tiba pendidikan bangsa ini telah dirancang atas landasan perundangan tertentu, sistematika perencanaan melalui mekanismemekanisme yang bersama-sama ditetapkan, dan dibarengi implementasi yang seksama mungkin.

Hal-hal yang diuraikan di atas telah menjadi tantangan dan sekaligus tanggungjawab para pelaku pendidikan di Indonesia untuk mencari solusi pemecahan dan penyelesaian. Para ahli dan pakar pendidikan tentu memiliki tanggungjawab yang lebih spesifik, yakni menyangkut bangunan ilmu pendidikan. Makanya penulis sangat setuju dengan apa yang dicanangkan oleh pemerintah tentang pelaksanaan wajib belajar 9 tahun,(Muhaimin;2005:245). yaitu pendidikan Dasar (SD/MI dan SLTP/MTs). Untuk menjawab persoalan-persoalan yang dihadapi 
pendidikan bangsa Indonesia, dan sekaligus tanggungjawab madrasah dalam menatap pendidikan Indonesia ke depan.

\section{Eksistensi Madrasah}

Berbicara masalah eksistensi madrasah, maka hal tersebut hendaknya mempunyai landasan tentang peningkatan mutu madrasah. Sehingga dengan landasan tersebut akan menjadi penguat, sebagaimana dalam penjabaran Keppres No. 34 tahun 1772 dan Ipres No. 15 Tahun 1972 pada tahun 1973 dalam bentuk usaha peningkatan mutu madrasah melalui Surat Keputusan Bersama (SKB) Tiga Menteri, yaitu Mendikbud, Mentri dalam Negeri, dan Menteri Agama No. 6 Tahun 1973, No, 037/U/1976 dan No. 36 tahun 1975. yang dalam hal tersebut menyebutkan bahwa agar dilakukan usaha bersama untuk meninkatkan mutu pendidikan pada madrasah sehingga kualitas pengetahuan umum siswa madrasah bisa mencapai tingkat yang sama dengan tingkat mata pelajaran umum siswa sekolah umum yang sederajat. Sehingga dengan demikian standar mata pelajaran umum pada madrasah sama dengan sekolah umum.

Pada sekarang ini, madrasah benar-benar sama dan sejajar dengan sekolah pada umumnya, karena pemerintah melalu PP No. 19/2005 tentang Standar Nasional Pendidikan dan Permendiknas No. 22, 23, 24 tahun 2006, telah memberikan standarisasi baik isi, proses, pengelolaan, dan penilaian terhadap semua bentuk dan jenis pendidikan formal di Indonesia mulai dari tingkat dasar sampai pendidikan tinggi baik ynag berupa sekolah umum maupun madrasah(Malik Fajar;2005:237).

Maka tidak heran kalau Departemen Agama (Depag) menetapkan sejumlah madrasah untuk dijadikan sebagai sekolah unggulan (madrasah model),(DepagRI; 1998:1). Tujuan yang ingin dicapai adalah agar madrasah tersebut menjadi "model" bagi madrasah di sekitar (madrasah satelit) yang jumlahnya sangat banyak. Dalam kaitan ini, Departemen Agama (Depag) dengan menggunakan dana bantuan berupa pinjaman lunak (loan) dari Asian Development Bank (ADB), telah menetapkan sejumlah madrasah pada tingkat Madrasah Ibtidaiyah Negeri (MIN) dan Madrasah Tsanawiyah Negeri (MTsN) menjadi madrasah model. Secara keseluruhan jumlah madrasah jumlah madrasah model di Indonesia terbagi atas; untuk tingkat MIN berjumlah 24 madrasah (empat di antaranya di Jawa Timur), dan MTsN berjumlah 15 madrasah (tiga di antaranya di Jawa Timur).

Hal tersebut merupakan sebagai acuan bahwa madrasah mampu meningkatkan kualitas pendidikan Indonesia dengan seoptimal dan menunjukkan eksistensi keberadaan madrasah. Maka madrasah pada hari sangat jauh perkembangannya dengan madrasah-madrasah sebelumnya, utamanya pada awal mula berdirinya. Maka tidak heran kalau dikalangan masyarakat berlomba-lomba memasukkan anak-anaknya ke madrasahmadarah. Karena madrasah menurut mereka mampu memberikan yang 
terbaik kepada anaknya, baik dalam disiplin ilmu-ilmu umum maupun ilmu-ilmu agama.

\section{E. Penutup}

Eksistensi madrasah dalam pendidikan Indonesia memberikan kontribusi yang sangat luar biasa terhadap kemajuan pendidikan Indonesia. Di mana hal tersebut dapat dilihat bahwa madrasah dijadikan perhatian pemerintah untuk semakin ditingkatkan dan dikembangkan, karena madrasah mampu mengaingi sekolah umum dan bahkan melebihinya. Maka pada sekarang ini tidak ada bedanya sekolah umum dengan madrasah, karena madrasah mampu memadukan desain sekolah umum dengan madrasah yang disebut dengan sekolah model (sekolah unggulan).

Keberadaan eksistensi madrasah juga dijadikan pilihan utama oleh masyarakat dalam meneruskan jenjang pendidikan anak-anaknya, baik dari setingkat Madrasah Ibtidaiyah (MI), Madrasah Tsanawiyah (MTs), dan Madrasah Aliyah (MA).

\section{F. DAFTAR PUSTAKA}

Al Jumlati, Ali., Perbandingan Pendidikan Islam, Jakarta: PT Rineka Cipta, 1994

Departemen Agama RI, Pedoman Pelaksanaan Pengembangan dan Pengelolaan Madrasah Model, Jakarta: Dirjen Binbaga \& Binrua, 1998

Fadjar, A. Malik., Madrasah dan Tantangan Modernis, Bandung: Mizan, 1998

., Visi Pembaruan Pendidikan Islam, Jakarta: Lembaga Pengembangan dan Penyusunan Naskah Indonesia (LP3NI), 1998 Persada, 2005

Hasbullah, Kapita Selekta Pendidikan Islam, Jakarta: PT RajaGrafindo Persada, 1996

Nasir, M. Ridlwan., Mencari Tipologi Format Pendidikan Ideal: Pondok Pesantren di Tengah Arus Perubahan, Yogyakarta: Pustaka Pelajar, 2005

Maksum, Madrasah Sejarah dan Perkembangannya, Jakarta: Logos Wacana Ilmu, 1999

Mastuhu, Memberdayakan Sistem Pendidikan Islam, Ciputat Jakarta: Logos Wacana, 1999

Muhaimin, Pengembangan Kurikulum Pendidikan Agama Islam: di Sekolah, Madrasah, dan Perguruan Tinggi, Jakarta: PT. RajaGrafindo Persada, 2005 
Samsul S.-Eksistensi Madrasah dalam Pendidikan Indonesia

Steenbrink, Karel A., Beberapa Aspek tentang Islam di Indonesia Abad ke-19, Jakarta: Bulan Bintang, 1984

., Pesantren Madrasah Sekolah, Jakarta: LP3ES, 1991

Undang-Undang Republik Indonesia Nomor 20 Tahun 2003 Tentang, Sistem Pendidikan Nasional, Jakarta: Kaldera Pustaka Nusantara, 2003

Yunus, Mahmud., Sejarah Pendidikan Islam, Jakarta: Hidakarya Agung, 1982 